\title{
A Study of Customer Orientation and Customer Commitment in the Food Sector of Pakistan
}

\section{Muhammad Ahmad* and Mirza Ashfaq Ahmed**}

\begin{abstract}
This study examines the relationship of a firm's customer orientations, salesperson customer-oriented behavior and customer intimacy with customer commitment. For the purpose of this study, the interpersonal relationship marketing model and the interpersonal attraction investment model are employed to propose the conceptual model. The conceptual model suggests that (1) firm's customer orientation positively influences the salesperson customer-oriented behavior; (2) salesperson customer-oriented behavior positively influences the customer intimacy; (3) customer-oriented behavior positively mediates between customer orientation and customer intimacy; and (4) customer intimacy acts a positive mediator between the salesperson customer-oriented behavior and customer commitment. Through the course of this study, the proposed conceptual models were tested with the data collected from the firm and customer dyads. Moreover, the data is collected from the food sector of Pakistan. Furthermore, the Smart-PLS is used to test the standardized dyadic data sets. Results have provided substantial support for the proposed conceptual model. There is strong support for the salesperson customer-oriented behavior, and customer intimacy as mediator. Additionally, the results validate the interpersonal relationship marketing model and the Rusbult investment model as well. From a managerial perspective, this study can help organizational policy makers to understand the importance of salesperson behavior, and customer emotions for a long-term relationship with the targeted customer of the specific firm.
\end{abstract}

Keywords: Customer orientation, customer-oriented behavior, customer intimacy, commitment, dyadic data, interpersonal relationship

JEL Classification: L66, M31, O53.

\footnotetext{
${ }^{*}$ PhD Scholar, Department of Management Sciences, University of Gujrat, Gujrat, Pakistan.

*** Assistant Professor, Department of Management Sciences, University of Gujrat, Pakistan.
} 


\section{Introduction}

Over past few years, the food sector of Pakistan has been passing through some radical changes. This change is evident in multiple ways e.g., growth, variety, taste and competition. The food sector serves a diversified set of customers in terms of gender, age, preferences, and income levels. Customers of the food sector are now much aware, they are taste divergent, prefer customized recipes, and are definitely more health conscious (Bihamta, Jayashree, Rezaei, Okumus, \& Rahimi, 2017). Furthermore, customers play multiple roles during their food consumption experience. For example, as the co-producer, co-distributer, co-promoter, comanufacturer, consumer as innovator, co-evaluator, co-designer, co-ideator, and finally as a co-tester (Tardivo, Thrassou, Viassone \& Serravalle, 2017).

Moreover, there is mushroom growth in the amount of food providers, and also a shift in the spending patterns. For instance, the packaged food spending has increased from US \$ 2.50 in 2003-2004, to US \$ 7.50 in 2013-2014 (Pakistan Bureau of Statistics, 2015). The use of processed and pre- cooked food is not only popular in urban families, but is a phenomenon that is gaining popularity in rural families as well. There are a number of national and international players that are entering in the food sector. The concept of food web portals e.g., are also active in the food businesses and contribute towards the growth in customer traffic. With such numerous opportunities and challenges, firms of all scales (large, medium, and small) are striving hard to maintain close relationships with customers. In this regard, customer commitment is marked as a cornerstone of a firm's success to achieve long-term competitive advantage (Hsiao, Shen, \& Chao, 2015).

This research is based on the interpersonal relationship marketing model (Palmatier, 2008) and the Rusbult (1980) investment model. In this study, it is proposed that customer commitment is a result of a firm's customer orientation, salesperson customer-oriented behavior and customer intimacy. Customer orientation is the firm's philosophy and business strategy that it adopts in order to serve its customers. It refers to a set of beliefs that put the customer's interests first in order to develop a long-term profitable relationship (Deshpandé, Farley \& Webster, 1993). Customer orientation is translated into salesperson customer-oriented behavior, which means that employees understand customers, have 
adequate knowledge about customers, and demonstrate learning orientation (Bagozzi, Verbeke, van den Berg, Rietdijk, Dietvorst, \& Worm, 2012). Customer intimacy is defined as "customer's perception of close and valued relationship with seller, with high level of mutual understanding" (Brock \& Zhou, 2012, p.371). Moreover, customer intimacy is marked as a component of warmth in the aspect of customer relationship (Bugel, Verhoef, \& Buunk, 2011), and is gaining popularity in marketing literature (Balaji, Roy \& Wei, 2016; Beetles \& Harris, 2010; Bugel et al., 2011; DeJager, Cirakoglu, Nugter, \& van Os, 2017; Gottman, 2007; Ponder, Holloway, \& Hansen, 2016; Yim, Tse, \& Chan, 2008). Finally, the interpersonal relationship marketing perspective is also getting popularity in the field of marketing research (Balaji et al., 2016; Hasan, Mortimer, Lings \& Neale, 2017; Palmatier, Jarvis, Bechkoff, \& Kardes, 2009).

Pertaining to this particular study, the research objectives are to examine the positive relationship between firm's customer orientation, and salesperson customer-oriented behavior. This study also examines the positive relationship between salesperson customer-oriented behavior and customer intimacy. Furthermore, this study aims to investigate the mediating role of customer-oriented behavior between customer orientation and customer intimacy. Finally, the objective of this research is also to evaluate the mediating role of customer intimacy between the salesperson customer-oriented behavior and customer commitment.

It must be known that this study contributes to marketing literature in several ways. The first one being that in this study, customer orientation is studied with respect to large, medium, and small organizations; however, previous researches mainly focus on large and medium sized organizations (Herrero, Martín, \& Collado, 2018). Secondly, the interpersonal relationship marketing model is extended by incorporating customer intimacy (Balaji et al., 2016; Bugel et al., 2011) and the Rusbult (1980) investment model. Thirdly, the dyadic survey methodology is used to test the proposed model. And lastly, this research provides external validity to the proposed model in a different context. 


\section{Literature Review}

\subsection{Customer Orientation}

Customer orientation is defined as a "set of believes that puts the customer's interest first, but it does not exclude stakeholders such as owners, managers, and employees in order to develop a long-term profitable enterprise" (Deshpande et al., 1993, p.27). Customer value and customer service are ingrained believers in organizational memory. Organizational behavior, and its decision making are influenced by the aforementioned beliefs (Zablah, Franke, Brown, \& Bartholomew, 2012). Customer orientation is marked as a key business strategy that helps understand its customers, source of competitive advantage, and supports the management to achieve their business objectives (Zhang \& Yang, 2018). Moreover, deep rooted customer orientation among the employees leads to novel solution of customers' queries, and better customer service (Babakus, Yavas, \& Karatepe, 2017). Employees with customer orientation intentions have better learning, knowledge enhancement, and superior understanding of the customers' requirements (Bagozzi et al., 2012). Furthermore, customer orientations which are referred to as cultural phenomenon, have five dimensions. These dimensions include the ability to pamper the customers, to deliver service, read the customer facet, maintain personal relationships, and keeping the customer informed. These abilities of employees help to achieve the customers' commitment to any organization (Kanten, Kanten, \&Baran, 2016). Furthermore, it is advocated that the organizational customer orientation strategy helps to describe the employees' job attitude and behavior (Jeng, 2018) which ultimately affect the customers of the organization (Sousa \& Coelho, 2011).

The application and advancement of customer orientation is overwhelmingly accepted in contemporary marketing research. Furthermore, it is advocated as a business strategy that is a source of competitive advantage. Additionally, it must be known that it is the prime priority of researchers since a number of years (Bharadwaj, Nevin, \& Wallman, 2012; Papaioannou, Kriemadis, Kapetaniou, Yfantidou, \& Kourtesopoulou, 2018). Contemporary research in customer orientation advocates several inferences. For instance, these key inferences include: i) customer orientation enhances front line employees' creativity (Jeng, 2018); ii) customer orientation positively impacts the product development 
(Zhang \& Yang, 2018); and iii) customer orientation strategy in tourism and hospitality industry positively impacts the business performance (Papaioannou et al., 2018). Other examples may include observations such as customer orientation positively influences performance of hospitality microenterprises (Herrero et al., 2018), customer orientation improves the performance in buyer and seller relationship (Leckie, Widing \& Whitwell, 2017) and finally, customer orientation moderates between work engagement and employee turnover intentions in hospitality sector (Babakus et al., 2017). Furthermore, dwelling into the examples, we may also consider that organization customer orientation positively influences the salesperson customer orientation (Varghese, Edward, \& George, 2017). Thus, it can be inferred that customer orientation is an important facet of organizational agility (Kanten, Kanten, Keceli, \& Zaimoglu, 2017).

From the above discussion, it can be conceptualized that customer orientation is an important business strategy which influences the behavior and motivation of employees (Zablah et al., 2012) and consequently, the customers' service and value (Sousa \& Coelho, 2011). This focal point of this research is existence of interpersonal relationships, and how they play a part in the customer orientation and commitment towards a particular food brand. The interpersonal relationship marketing theory is concerned about understanding the customers' needs, emotions, and social genetic. The synergy of the aforementioned customers' measures results in a sustainable and long-term relationship with customers (Palmatier, 2008). A customer-oriented firm designs and executes such strategies that result in positive customer outcomes (Brady \& Cronin, 2001). Moreover, interpersonal relationship marketing advocates that firms' efforts to maintain the relationship tend to create customer intimacy (Balajiet al., 2016; Hasan et al., 2017). Finally, it is also concluded that the customer orientation philosophy affects the salesperson customer-oriented behavior, and customer intimacy. Keeping these insights in mind, the following hypotheses are proposed:

Hypothesis 1: Customer orientation is directly and positively related with the salesperson customer-oriented behavior.

Hypothesis 2: Customer orientation is directly and positively linked with the customer intimacy. 


\subsection{Salesperson Customer-oriented Behavior}

Salesperson customer-oriented behavior is a result of the organizational customer orientation philosophy, and marketing strategy (Brady \& Cronin, 2001; Jeng, 2018; Kanten et al., 2017; Leckie, Widing \& Whitwell, 2017; Periatt, LeMay \& Chakrabarty, 2004; Saxe \& Weitz, 1982; Varghese et al., 2017). Salesperson customer-oriented behavior leads to better customer services (Sousa \& Coelho, 2011), helps maintain long-term relationship with customers (Kelley, 1992), and provides better service quality for customers (Brady \& Cronin, 2001). Moreover, it leads to better customer satisfaction (Lussier \& Hartmann, 2017), and bring internal marketing benefits e.g., job commitment, satisfaction, and organizational citizenship behavior (Donavan, Brown, \&Mowen, 2004). There are a number of combinations of training and skills development programs to impart customer-oriented behavior in the salespersons of a particular organization (Hennig-Thurau \&Thurau, 2003). Furthermore, organizations provide better rewards, empower (Ro \& Chen, 2011), and improve employee engagement for better salesperson customer-oriented behavior (Babakus et al., 2017).

Studies show that there is a positive relationship between the employees' customer-oriented behavior and the customers related and relevant outcomes (Babakus et al., 2017; Bagozzi et al., 2012; Sousa \& Coelho, 2011). Customer-oriented behavior helps to form personal relationships with customers (Kanten et al., 2016). Moreover, the interpersonal relationship marketing theory advocates that the sellers' efforts help to create emotional ties and commitments with the targeted customers (Hasan et al., 2017; Palmatier, 2008; Palmatieret al., 2009). Previous studies have established the relationship between an employee's customer-oriented behavior, and the customer commitment, satisfaction, and retention (Hennig-Thurau, 2004). Intimacy refers to "feelings of closeness, connectedness and bonding that exists in loving relationships" (Sternberg, 1986); whereas, customer intimacy is defined as a "customer's perception of close and valuable relationships with sellers, that is marked with a higher level of understanding" (Brock \& Zhou, 2012).

According to Bugel et al. (2011), customer intimacy meant an affective internal state of customers. Customer intimacy is related to the closeness and connectedness of customers with the firm. It is also an essential part of interpersonal relationship (Laurenceau, Barrett, \& 
Pietromonaco, 1998). A firm's efforts to develop interpersonal relationships is one of the many ways to develop and maintain positive customer intimacy. One example of this may be the efforts made to nurture effective communication (Balaji et al., 2016). In this research, customer orientation philosophy and salesperson customer-oriented behavior are considered as important sources to create customer intimacy. Furthermore, salesperson customer-oriented behavior also affects the customers' commitment towards a particular firm. Relationship marketing theory states that committed customers show positive behavior when it comes to the organization that they favor, and likely to patronize other organizations (Morgan \& Hunt, 1994). Additionally, salesperson customeroriented behavior mediates between customer orientation and customer intimacy. Keeping these insights in mind, the following hypotheses are presented.

Hypothesis 3a: Salesperson customer-oriented behavior is directly and positively related with the customer intimacy.

Hypothesis 3b: Salesperson customer-oriented behavior mediates the link between customer orientation and customer intimacy.

Hypothesis 3c: Salesperson customer-oriented behavior is directly and positively related with the customer commitment.

\subsection{Customer Intimacy}

The notion of intimacy is derived from the Latin word "intimatus", in early 17th century, which meant familiarity or keeping a close connection (Yim et al., 2008). Intimacy is a multifaceted phenomenon e.g., mutuality, caring, and interdependence are all characteristics that fall within the realm of intimacy (Ben-Ari \&Lavee, 2007; Rokach \& PhilibertLignieres, 2015). The concept and subject of intimacy is gaining popularity in the literature for marketing and interpersonal relationship marketing (Gottman, 2007; Yim et al., , 2008; Beetles \& Harris, 2010;Bugel et al., 2011; Balaji et al., 2016; Ponder et al., 2016; De Jager et al., 2017). Moreover, Bugel et al. (2011) noted that the majority of research conducted on customer relationships has completely ignored the research on element of sustainability in love and the intimacy in relationships. 
Intimacy is often confused with positive terms such as passion and commitment. However, Yim et al. (2008) found intimacy as an empirically distinct construct. Intimacy may be constructed of multiple types (Schaefer \& Olson, 1981), and can hold a number of components (Stern, 1997). The research confirmed the existence of emotions based intimacy between a seller's and buyer's relationship (Yim et al., 2008). According to Hansen (2003), customer-oriented behavior of the employees of an organization is an important antecedent of customer intimacy. Moreover, customer intimacy is found to be an important predictor of customer commitment in multiple services sectors (Balaji et al., 2016). Customer commitment is defined as a "customer's desire to maintain a valued relationship with a brand due to previous satisfactory interactions with it" (Hsiao et al., 2015; Jones, Fox, Taylor, \& Fabrigar, 2010).

In relationship marketing literature, the concept of commitment has received special attention (Balaji et al., 2016). Commitment may be of different natures. These include affective, continuance or calculative and normative types of commitment (Jones et al., 2010). Moreover, the concept of commitment refers to both the attitudinal (Srivastava\& Owens, 2010) and behavioral (Ashley \& Leonard, 2009) meanings. In the relationship between these two parties, it is actually the willingness to make short term sacrifices, in order to comprehend and realize the long term benefits (Dwyer, Schurr, \& Oh, 1987). Commitment portrays the motivation of customers to actually maintain a relationship. Furthermore, customers share positive feelings about the firm in question. Therefore, commitment is marked as an essential element for the creation, and continuance of a marketing relationship (Lacey, 2007). Moreover, the interpersonal relationship marketing theory implies that an emotional bond, for example, customer intimacy (Balaji et al., 2016), creates a cyclic effect of emotional debt that is paid in the form of customer commitment and longterm customer relationship (Palmatier, 2008). Keeping these insights in mind, the following hypotheses are proposed:

Hypothesis 4a: Customer intimacy is directly and positively associated with the customers' commitment.

Hypothesis 4b: Customer intimacy mediates the relationship between salesperson's customer-oriented behavior and customer commitment. 


\subsection{Conceptual Model}

The conceptual model is based on the interpersonal relationship marketing model (Palmatier, 2008) and the Rusbult's (1980) investment model, in order to study the close relationships between buyers and sellers. The interpersonal relationship marketing model puts forth that the sellers' efforts such as the inclination towards customer orientation (Deshpande et al., 1993) and stimulate the customers' emotions. An example of this may be customer intimacy (Balaji et al., 2016), which creates an emotional debt, and results in the customers paying off the emotional debt in the form of showing his/her commitment towards the organization (Palmatier, 2008). This process creates a cycle, and a long-term seller and customer relationship. Moreover, customer relationship with an individual e.g., employee, is stronger as compared to the customers' relationship with the seller (Palmatier, 2008). The rationale behind this strong bond is that the customers feel intimate affection and love towards a particular brand or organization (Bugel et al., 2011). Moreover, when applying the Rusbult (1980) investment model i.e., reinforcement (i.e., sellers' efforts to maintain relationship with customers) from one party in the relationship (Perlman \& Fehr, 1986) is a fundamental preamble in order to create an intimate relationship (Bugel et al., 2011). The literature is mostly skewed towards trust (Bugel et al., 2011) and ignores the customer intimacy aspect. Therefore, this particular research examines customer orientation, customer intimacy, and customer commitment.

In this conceptual model, the salesperson customer-oriented behavior mediates between the customer orientation and the customer intimacy; similarly, customer intimacy mediates between a salesperson's customeroriented behavior, and a customer's commitment. Considering multiple mediators, researchers analyze the model that includes all the relevant mediators at the same time (shown in the Figure-1). For such a mediating model, it is essential to consider the multi-mediator model. The PLS-SEM technique allows us to analyze both single and multiple mediation models (i.e., parallel and serial mediation) (Carrión, Nitzl, \& Roldán, 2017; Ghazali, Mutum, \& Woon, 2019; Hair, Hult, Ringle, \& Sarstedt, 2016; Nitzl, Roldan, \& Cepeda, 2016; Zhao, Lynch, \& Chen, 2010). Methodological researches in management sciences have suggested PLS-SEM for handling multilevel modeling. Moreover, it is used as a multilevel analysis tool in marketing research (Ali, Rasoolimanesh, Sarstedt, Ringle, \&Ryu, 2018; Hwang, Takane, 
\& Malhotra, 2007; Lussier \& Hartmann, 2017; Richter, Cepeda-Carrión, Roldán, \& Ringle, 2016).

Figure 1: Conceptual Model

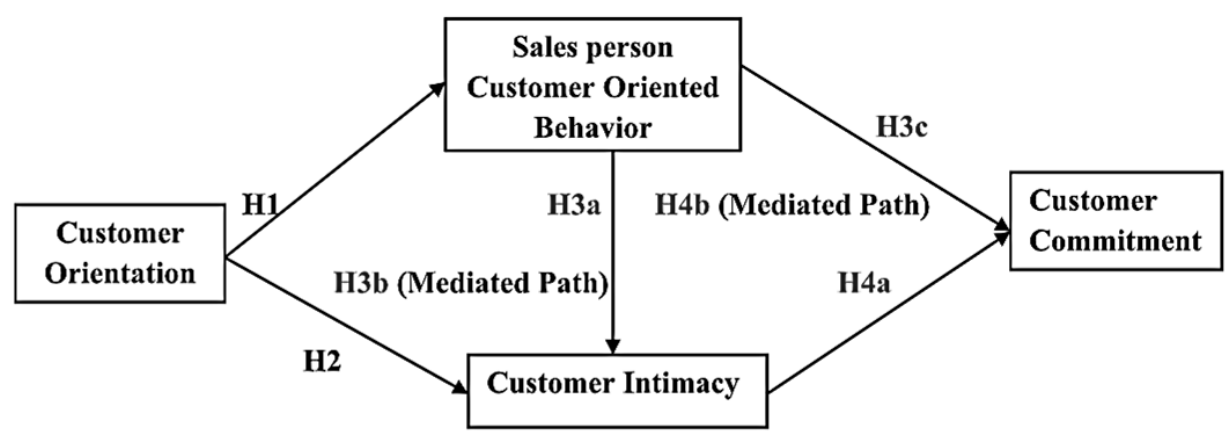

\section{Research Methodology}

The hypotheses are tested with the data collected from the food sector of Pakistan. The data set is dyadic in nature (Lussier\& Hartmann, 2017). A self-administrated survey questionnaire was used for data collection from both the sellers and buyers. The scales used for data collection are adapted and have established the validity and reliability over time. The measures used were adapted from the following sources; the customer orientation was measured with nine (9) items (Deshpande et al., 1993), the salesperson customer-oriented behavior was measured with five (5) items (Periatt, LeMay, \& Chakrabarty, 2004), customer intimacy was measured with three (3) items (Balaji et al., 2016), and the customer commitment is measured with three (3) items (Balaji et al., 2016). Items of each construct are given in Annexure-1.

The dyadic data set holds some special characteristics mainly: distinguishability and Non-independence. The Dyadic data may consist of the standard dyadic design, Social Relations Model (SRM) design, and onewith-many design (Kenny, Kashi, \& Cook, 2006). The data set of this research follows the standardized dyadic patterns. This type of dyad means that there is equal representation of the relationship partners. The survey questionnaire was divided into two parts (A and B). Part-A is used to collect data from the sellers (customer orientation data is provided by sellers), and Part-B is used to collect data from the buyers (salesperson customer-oriented behavior, customer intimacy, and customer commitment data is provided 
by the buyers). From the sellers' side, representatives of the sellers are requested data collection including chief executive officers (CEOs), managers, shift in-charge officers, customer service representatives, relationship managers and similar position holders in food restaurants and chains. Customers filled part-B (Buyers side) of the survey questionnaire.

\subsection{Sample}

Utmost care and systematic process was carried out in order to collect data from the seller and buyer dyads. The sample represents the food sector of Pakistan. Both conventional (local) food restaurants, and the outlets of fast food chains were approached to collect data. Different sampling techniques were used to collect data from the sellers' side and buyers' side. Certain sampling rules were set before the data collection exercise, and they were strictly followed and implemented in order to maintain the accuracy and sanctity of the data. This also helped to overcome the occurrence of any non-response bias. First, consistent with the objective of this research, the authors were interested to study the mature relationships between the sellers and buyers. Second, only those sellers' representatives (working for more than two years with the same organization) and buyers, who had been customers of the same organization for more than two years, were targeted. Furthermore, the customers must have visited the restaurant or outlet at least once in the last three months.

The sellers' data was collected from the seller's representatives in restaurants and fast food chains operating in Gujrat, Wazirabad, and Gujranwala. Multinational fast food chains for example KFC, McDonald's are considered to be large organizations; restaurants that have national presence, for instance Shehbaz Tikka, are classified as medium sized organizations, and local restaurants including Loaf and Leaf are classified into small organizations. From the buyers' side of the data that was collected, quota sampling with convenience was used. However, customers were supposed to fulfill the qualification criterion used to collect the data. In this report, a final sample data set consists of one hundred and twenty-one (121) standardized dyads. Among the sample 27 outlets (22.31\%) were fast food outlets (both local and international chains); whereas, 94 outlets $(77.69 \%)$ were famous local food restaurants and bakers. 


\subsection{Data Analysis and Common Method Variance}

Partial least squares structural equation modeling (PLS-SEM) is used to test the hypotheses of the proposed conceptual model. SmartPLS version 3.2.1 (Ringle, Wende, \& Becker, 2015) is the software package used for the required analysis. PLS-SEM is a variance based approach of SEM (Chou \& Chen, 2018; Hair, Sarstedt, Ringle, \& Mena, 2012; Hair, Sarstedt, Hopkins, \& Kuppelwieser, 2014; Hair, Hult, Ringle, Sarstedt, \& Thiele, 2017). The rationale to use PLS-SEM include the fact that firstly, the data is non-normal, secondly, the sample size is small (Chin, 1998) and thirdly, the analysis is carried out regardless of the reflective-formative constructs (Hair et al., 2014) considerations. The PLS-SEM seeks to maximize the variance that is explained in the endogenous variables. It is useful for the complex model analysis, and is also used for prediction (Chou \& Chen 2018; Hair et al., 2017; Ringle \& Sarstedt, 2016). PLS-SEM simultaneously also investigates the measurement and structural model. It provides both reliability and validity. The measurement model assesses the relationship between measures and constructs (Lohmoller, 1989). Whereas, the structural model explains the relationship among the constructs (Hair et al., 2014). The hierarchal latent structural model is analyzed with a procedure carried out originally by Lussier and Hartmann (2017). Furthermore, the PLS-SEM allows for the serial mediation analysis (Carrión et al., 2017; Ghazali, Mutum, \&Woon, 2019; Hair et al., 2016; Nitzl et al., 2016; Zhao et al., 2010). Finally, the popularity of PLS-SEM in the top marketing journals (Ahearne, MacKenzie, Podsakoff, Mathieu, \& Lam, 2010; Bolander, Satornino, Hughes, \& Ferris, 2015; Hair et al., 2014) provides the foundations to use it as a dyadic data analysis tool.

The measures used in the structural model are reflective in nature. Reflective measures are linked to a variable through the loading technique. These loading variables are bivariate correlations between the measure and the variable. It is noteworthy that the reflective model specification need both reliability and validity (Hair et al., 2014). Consistent to the recommendations (Rungtusanatham, Miller, \& Boyer, 2014) and hypotheses of this research; both the direct path and the indirect relationship paths (mediated path) are modeled. Moreover, the nonparametric bootstrapping of 5000 replications (Akter, Wamba, \&Dewan, 
2017 ) is carried out for the standard error, and to assess whether the values change or not (Chin, 2010; Hair et al., 2016).

The predictors such as the customer orientation and outcome, which may include the customer commitment, are assessed with the data from different sources. These sources can include the sellers and the customers. This method helps to overcome the common method variance (CMV), as this data set is based on the data collected from multiple sources (Podsakoff, MacKenzie, Jeong-Yeon, \& Podsakoff, 2003). CMV is the variance based attribute that may lead to a bias in the findings of the correlation research, by increasing or decreasing the strength of the relationship between the variables (Podsakoff et al., 2003). In order to avoid the confusion and complexity, a separate questionnaire was formulated to tap the sellers and the customers' responses

\section{Results}

\subsection{Sample Characteristics}

Table-1 depicts the demographic profile of the respondents. The data set is dyadic in nature; therefore, the sample composition is also twofold (characteristics of sellers and buyers), with respect to the buyer sample characteristics, that is the gender, age, occupation, income, and education of the respondents. With respect to the sellers, the characteristics in question are presented in terms of gender and education, as presented in Table- 1. Among the buyers, there are 74 male and 47 female respondents. Most of the buyers represent the age group between 21-30 years, with 49 respondents in total. With respect to the occupation of most buyers, the respondents were students and job holders. The respondents' income level from the buyers' side is between fifty thousand to one hundred thousand rupees. Moreover, most of the buyers' respondents are graduates when it comes to education. From the sellers' perspective, the representation with respect to gender is 97 males and 24 females who participated, and filled the survey forms. Finally, as for the as the education level of the sellers' respondents is concerned, most of the respondents were graduates. 
Table 1: Sample Characteristics

\begin{tabular}{|c|c|c|c|c|c|}
\hline \multicolumn{3}{|c|}{ Seller } & \multicolumn{3}{|c|}{ Buyer } \\
\hline \multicolumn{3}{|c|}{ Gender } & \multicolumn{3}{|c|}{ Gender } \\
\hline Category & Frequency & Percentage & Category & Frequency & Percentage \\
\hline Male & 97 & 80.16 & Male & 74 & 61.15 \\
\hline Female & 24 & 19.83 & Female & 47 & 38.84 \\
\hline \multicolumn{3}{|c|}{ Education } & \multicolumn{3}{|c|}{ Education } \\
\hline Upto Intermediate & 11 & 9.09 & Upto Intermediate & 37 & 30.58 \\
\hline Graduation & 93 & 76.86 & Graduation & 60 & 49.59 \\
\hline \multirow[t]{17}{*}{ Above Graduation } & 17 & 14.04 & Above Graduation & 24 & 19.83 \\
\hline & & & \multicolumn{3}{|c|}{$\begin{array}{ll}\text { Age (years) } \\
\end{array}$} \\
\hline & & & Below 20 & 25 & 20.66 \\
\hline & & & $21-30$ & 49 & 40.49 \\
\hline & & & $31-40$ & 37 & 30.58 \\
\hline & & & Above 40 & 10 & 8.26 \\
\hline & & & \multicolumn{3}{|c|}{ Occupation } \\
\hline & & & Student & 55 & 45.45 \\
\hline & & & Job Holder & 47 & 38.84 \\
\hline & & & Businessman & 12 & 9.91 \\
\hline & & & Oversees & 7 & 5.79 \\
\hline & & & \multicolumn{3}{|c|}{ Income Monthly (Rupees) } \\
\hline & & & Below 50,000 & 35 & 28.93 \\
\hline & & & $51,000-100,000$ & 43 & 35.54 \\
\hline & & & $100,001-200,000$ & 21 & 17.35 \\
\hline & & & $200,001-400,000$ & 16 & 13.22 \\
\hline & & & Above 400,000 & 6 & 4.96 \\
\hline
\end{tabular}

\subsection{Measurement Model}

Table-2 highlights the outer loads and VIF (variation inflation factor) values of the measures of each latent variable. These parameters are used to access the validity and reliability of the measurement model. The bench mark value for outer loads is above .70, and below 5 for VIF (Hair et al., 2014). VIF values below 5 mean there is non-existence of collinearity. The presence of collinearity in PLS-SEM creates estimation issues in the model (Hair et al., 2014). In this regard, all values match the benchmark criteria of the values except one in the outer load (customer orientation measure 3), and one VIF value (Intimacy measure 2). The smaller fraction (one or two values of measurement model) from the benchmark. Values may not create measurement problems in the analysis (Bihamta et al., 2017). The values indicate fitness of measures and the non-existence of collinearity in the PLS-SEM measurement model. 
Table 2: Factor Loadings and Variance Inflation Factors (VIFs)

\begin{tabular}{lccccc}
\hline & $\begin{array}{c}\text { Customer } \\
\text { Orientation }\end{array}$ & $\begin{array}{c}\text { Salesperson } \\
\text { Customer-oriented } \\
\text { Behavior }\end{array}$ & $\begin{array}{c}\text { Customer } \\
\text { Intimacy }\end{array}$ & $\begin{array}{c}\text { Customer } \\
\text { Commitment }\end{array}$ & $\begin{array}{c}\text { Variance } \\
\text { Inflation } \\
\text { Factor (VIF) }\end{array}$ \\
\hline CO1 & .792 & & & & 2.873 \\
CO2 & .714 & & & & 2.669 \\
CO3 & .604 & & & & 1.920 \\
CO4 & .796 & & & & 2.374 \\
CO5 & .779 & & & & 2.335 \\
CO6 & .743 & & & & 2.519 \\
CO7 & .722 & & & & 2.137 \\
CO8 & .715 & & & & 1.967 \\
CO9 & .703 & & & & 1.993 \\
SOB1 & & .887 & & & 3.131 \\
SOB2 & & .852 & & & 2.979 \\
SOB3 & & .745 & & & 2.175 \\
SOB4 & & .771 & & & 1.839 \\
SOB5 & & .727 & & & 1.743 \\
INT1 & & & & 4.502 \\
INT2 & & & & 5.966 \\
INT3 & & .959 & & 2.252 \\
COMIT1 & & .857 & & 2.234 \\
COMIT2 & & & & & 2.038 \\
COMIT3 & & & & & 1.718 \\
\hline
\end{tabular}

\subsection{Descriptive Statistics}

The results of the descriptive statistics are presented in Table-3. With respect to the descriptive statistics, the mean values and standard deviation (SD) values are given. According to the results, the mean values are above 3.50. This means that the responses recorded against each of the variables are towards the "agree" option. Moreover, the SD values are less than 1.

\subsection{Reliability and Validity}

Both the reliability and validity are recommended for the reflective measures (Hair et al., 2014). The composite reliability (CR) provides a more appropriate measurement of the internal consistency (Hair et al., 2014). Results of CR are presented in Table-3. Moreover, the convergent validity is accessed with AVE. the results provide support to the convergent validity, as the AVE values are above 0.5 (Hair et al., 2014). 
Table 3: Descriptive Statistics, Reliability, and Convergent Validity

\begin{tabular}{lcccc}
\hline Construct & Mean & SD & CR & AVE \\
\hline Customer Orientation & 3.92 & .56 & .912 & .536 \\
$\begin{array}{l}\text { Salesperson Customer- } \\
\text { oriented Behavior }\end{array}$ & 3.96 & .57 & .898 & .638 \\
Customer Intimacy & 3.80 & .76 & .939 & .838 \\
Customer Commitment & 3.67 & .69 & .900 & .749 \\
\hline
\end{tabular}

The Heterotrait-Monotrait Ratio (HTMT) and the Fornell-Larcker Criterion are presented in Table 4. The HTMT ratio helps to determine the systematic discriminant validity assessment of a variable. It is an advanced statistical technique developed by Henseler, Ringle, and Sarstedt (2015). Moreover, it suggested that the HTMT ratio values should be below 0.85 (Chan \& Lay, 2018; Franke \& Sarstedt, 2019; Henseler et al., 2015). Results provide support for the discriminant validity. Furthermore, the FornellLarcker Criterion is the square root AVE of each variable. It applies that the squared correlation between the two variables should be greater than any of the two variables (Henseler et al., 2015). The Fornell-Larcker Criterion results are given in bold against the HTMT values in Table 4.

Table 4: Heterotrait-Monotrait Ratio (HTMT) and Fornell and Larcker Criterion

\begin{tabular}{lcccc}
\hline Construct & $\begin{array}{c}\text { Customer } \\
\text { Orientation }\end{array}$ & $\begin{array}{c}\text { Salesperson } \\
\text { Customer-oriented } \\
\text { Behavior }\end{array}$ & $\begin{array}{c}\text { Customer } \\
\text { Intimacy }\end{array}$ & $\begin{array}{c}\text { Customer } \\
\text { Commitment }\end{array}$ \\
\hline $\begin{array}{l}\text { Customer Orientation } \\
\text { Salesperson Customer- }\end{array}$ & .732 & & & \\
oriented Behavior & .726 & .799 & & \\
Customer Intimacy & .489 & .728 & .916 & \\
Customer Commitment & .453 & .794 & .775 & .866 \\
\hline
\end{tabular}

\subsection{Intra-Class Correlations}

An interclass correlations (ICC) is the measure to estimate the interrater reliability of the data. It is a reflection of variation between 2 or more raters of the same subject. The One-Way Random-Effects model is applied to access ICC because there was a different set of raters randomly chosen from a larger population of possible raters (Koo \& Li, 2006). Before applying bootstrapping to access the effect decomposition, the ICC is 
applied; results of which are presented in Table-5, and support that there is a significant inter-rater reliability in the data.

Table 5: Intraclass Correlation Coefficient

\begin{tabular}{lccccccc}
\hline & $\begin{array}{l}\text { Intraclass } \\
\text { Correlation }\end{array}$ & \multicolumn{2}{c}{$\begin{array}{l}\text { 95\% Confidence } \\
\text { Interval }\end{array}$} & \multicolumn{3}{c}{ F-test with True Value 0 } \\
\cline { 3 - 8 } & & $\begin{array}{l}\text { Lower } \\
\text { Bound }\end{array}$ & $\begin{array}{c}\text { Upper } \\
\text { Bound }\end{array}$ & Value & df1 & df2 & $\begin{array}{c}\text { Significance } \\
\text { value }\end{array}$ \\
\hline Single Measures & .371 & .311 & .442 & 12.798 & 120 & 2299 & .000 \\
Average Measures & .922 & .900 & .941 & 12.798 & 120 & 2299 & .000 \\
\hline
\end{tabular}

One-way random effects model where people effects are random.

\subsection{Direct and Indirect Effects}

Table 6 presents the effect of the decomposition of predictors, and the outcome variables. The output from the PLS-SEM provides simultaneous examination of the direct, indirect and total effects of the predictor, mediator and outcome variables. In Table-6, the results are presented with respect to the hypotheses proposed in the conceptual model (Figure 1). The detailed statistical analysis shows that customer orientation is found to be a significant predictor of salesperson customeroriented behavior $(\beta=0.648, p<0.001)$, and an insignificant direct predictor of customer intimacy $(\beta=0.068, p>0.05)$. The insignificant effect of customer orientation on customer intimacy consequently caused to reject H2. Salesperson customer-oriented behavior significantly mediates $(\beta=$ 0.394, $\mathrm{p}<0.001$ ) between customer orientation and customer intimacy. Results reveal that salesperson's customer-oriented behavior is a significant predictor of customer intimacy $(\beta=0.608, \mathrm{p}<0.001)$, and customer commitment $(\beta=0.406, \mathrm{p}<0.001)$. Moreover, customer intimacy is found to be a significant predictor of customer commitment $(\beta=0.417$, $\mathrm{p}<0.001)$, and eventually customer intimacy significantly mediates between salesperson customer-oriented behavior and customer commitment $(\beta=0.253, \mathrm{p}<0.001)$. The results highlight the acceptance of $\mathrm{H} 1, \mathrm{H} 3 \mathrm{a}, \mathrm{H} 3 \mathrm{~b}, \mathrm{H} 3 \mathrm{c}, \mathrm{H} 4 \mathrm{a}$, and H4b. 
Table 6: Effect Decomposition

\begin{tabular}{|c|c|c|c|c|c|c|c|c|c|}
\hline \multirow[b]{3}{*}{ Effect of } & \multicolumn{9}{|c|}{ Effect on } \\
\hline & \multicolumn{3}{|c|}{$\begin{array}{c}\text { Salesperson Customer- } \\
\text { oriented Behavior }\end{array}$} & \multicolumn{3}{|c|}{ Customer Intimacy } & \multicolumn{3}{|c|}{ Customer Commitmen } \\
\hline & Direct & Indirect & Total & Direct & Indirect & Total & Direct & Indirect & Tota \\
\hline $\begin{array}{l}\text { Customer } \\
\text { Orientation }\end{array}$ & $.648^{* * *}$ & & $.648^{* * *}$ & .068 & $.394^{* * *}$ & $.462^{* * *}$ & & & \\
\hline $\begin{array}{l}\text { Salesperson } \\
\text { Customer- } \\
\text { oriented } \\
\text { Behavior }\end{array}$ & & & & $.608^{* * *}$ & & $.608^{* * *}$ & $.406^{* * *}$ & $.253^{* * *}$ & $.660^{* * *}$ \\
\hline $\begin{array}{l}\text { Customer } \\
\text { Intimacy }\end{array}$ & & & & & & & $.417^{* * *}$ & & $.417^{* * *}$ \\
\hline
\end{tabular}

*** $p<0.001$

Table 7 highlights the hypotheses results. The model which proposed the relationships of the conceptual model are found to be supported. Overall, the results provide support to the proposed conceptual model. The specific examination depicts that customer orientation explains $42 \%$ of the variance in salesperson customer-oriented behavior. Moreover, customer intimacy is explained with $42.7 \%$ customer orientation and salesperson customer-oriented behavior; whereas, customer intimacy and salesperson customer-oriented behavior collectively explains $56 \%$ of the variance in customer commitment. The explained variance is assessed with the $\mathrm{R}^{2}$ values. These $\mathrm{R}^{2}$ values also depict how much the predictors explain the outcome variable.

\section{Table 7: Hypotheses Results}

\begin{tabular}{llc}
\hline & \multicolumn{1}{c}{ Hypothesized relationship } & Results \\
\hline H1 & Customer Orientation $\rightarrow$ Salesperson Customer-oriented Behavior & Supported \\
H2 & Customer Orientation $\rightarrow$ Customer Intimacy & Not Supported \\
H3a & Salesperson Customer-Oriented Behavior $\rightarrow$ Customer Intimacy & Supported \\
H3b & $\begin{array}{l}\text { Customer Orientation } \rightarrow \text { Salesperson Customer-oriented } \\
\text { Behavior } \rightarrow \text { Customer Intimacy }\end{array}$ & Supported \\
H3c & Salesperson Customer-oriented Behavior $\rightarrow$ Customer Commitment & Supported \\
H4a & Customer Intimacy $\rightarrow$ Customer Commitment & Supported \\
H4b & $\begin{array}{l}\text { Salesperson Customer-oriented Behavior } \rightarrow \text { Customer Intimacy } \\
\text { G Customer Commitment }\end{array}$ & Supported \\
\hline
\end{tabular}




\section{Discussion}

The objectives of this research is to understand the influence of customer orientation and salesperson customer-oriented behavior, on the customer intimacy and maintenance of customer commitment. Furthermore, this research is intended to analyze the mediation of salesperson customer-oriented behavior and customer intimacy. The results fulfill the objectives laid in this research.

This research focuses on the customer orientation strategy of the food sector, in order to create customer intimacy and customer commitment (Herrero et al., 2018). The results confirm that customer orientation business strategy, and customer-oriented behavior are important predictors of customer intimacy and customer commitment in the food sector of Pakistan (Bharadwaj, Nevin, \& Wallman, 2012; Kanten et al., 2017; Papaioannou et al., 2018; Varghese et al., 2017). The firms' customer focused strategy is translated on to the employee (customer-oriented behavior), and consequently helps to create and nurture the intimate relationship with customers (Babakus et al., 2017; Bagozzi et al., 2012; Sousa\& Coelho, 2011). This research extends and contributes to further understanding of interpersonal relationship marketing (Palmatier, 2008) by adding the customer orientation strategy as an important reinforcement (Rusbult, 1980) investment model (Perlman \& Fehr, 1986). Moreover, this research contributes in the understanding of the limitations that pertain to research of intimacy (Bugel et al., 2011). This research collected data from both the concerned parties (sellers and buyers). This dyadic data set helps to avoid the Common Method Bias (Podsakoff et al., 2003). Moreover, the dyadic data is standardized in nature (equal number of sellers and buyers), which is consistent to the previous researches conducted (Lussier\& Hartmann, 2017). Most of the dyadic research in relationship marketing theory and practice is conducted between business to business (B2B) perspectives (Lussier\& Hartmann, 2017). However, this research makes a unique effort to apply the interpersonal relationship marketing model to sellers and buyers (B2C) dyads (Iacobucci \& Ostrom, 1996).

The results of this study confirm that a firm's customer orientation business strategy is a key predictor that helps to create intimate customer relationships and customer commitment. It is also going to prove to be insightful towards building intimate relationships with customers, and 
enhance the customers' commitment in the food sector, as the customer base in this sector is diverse with respect to gender, age, taste, choices and preferences. In this regard, customer orientation strategy plays a vital role because it advocates to give priority to the customers (Bihamta et al., 2017). The philosophical assumption confirms that the customer services and care starts from the top philosophy and strategy of the business (Deshpandé et al., 1993; Zablah et al., 2012; Zhang \& Yang, 2018). It is from the top that it travels to the employees and then the employees serve the customers (Babakus et al., 2017).

Moreover, in order to enhance the customer commitment, the employees' customer-oriented behavior plays an important role in the positive total experience of the customers. It is necessary to develop knowledge, skills and abilities of the employees in the food sector to anticipate, actively listen, understand and effectively take care of the customers. Now a days, customers and sellers work together for value creation, specifically in food sector, where customers are co-producers, codistributers, co-promoters, co-manufacturers, and consumers as innovators, co-evaluators, co-designers, co-ideators, and co-testers (Tardivo et al., 2017). Therefore, employees need to be proactive, talented and display a natural expertise to respond to the queries of their customers. Nowadays, a savvy and informed customer is a common phenomenon. So, for the creation of intimate relationships with customers, it is the need of the hour to work towards the training and development of employees from this very perspective. This would help to a have fully satisfied and delighted customer of a restaurant, and customer commitment can also be achieved by enhancing the service and customer food experience.

\section{Conclusions}

The interpersonal relationship marketing model of this research is based on the interpersonal relationship marketing model and Rusbult investment model. This research is conducted in the food sector of Pakistan, and results confirm the proposed model. Findings of this model are consistent with the previous research findings. Furthermore, this research is an effort to overcome the limitations of the interpersonal relationship marketing research on emotions such as customer intimacy. Additionally, this research extends the existing interpersonal relationship marketing model by adding a feature for interpersonal attraction -Rusbult 
investment model perspective. Finally, there are number of managerial implications in the food sector and the generalization of this model can be extended by conducting research in other sectors as well.

\section{Limitations and Future Research Directions}

This study has multiple limitations. Firstly, the research focuses on the food sector only. It would be fruitful to test the viability of our framework in other sectors as well, for general theoretical predictions. Secondly, this research is carried out without differentiating the size of the firms considered in the food sector i.e. large, medium, and small. However, any research done in the future research may apply this conceptual model to a specific sized firm, such as large fast food chains. Moreover, this research follows a cross-sectional dyadic design for data collection. However, future research may use the longitudinal design, or the historical data of the food providing firms in order to analyze intimate and committed relationships. Future research may also consider the complexity of the job description (Jeng, 2018) and the customer orientation strategy in order to create intimate and committed customer relationships. 
Acknowledgements. Authors are grateful for the reviews and guidance from the following experts of PLS-SEM.

1. Joe Hair (Mitchell college of Business, University of South Alabama, USA, jhair@southalabama.edu)

2. Marko Sarstedt (Faculty of Economics and Management, Otto-vonGuericke University Magdeburg, Magdeburg, Germany, marko.sarstedt@ovgu.de)

3. Christian Ringle (Faculty of Management Science and Technology, Hamburg University of Technology (TUHH), Hamburg, Germany, c.ringle@tuhh.de) 


\section{References}

Ahearne, M., MacKenzie, S. B., Podsakoff, P. M., Mathieu, J. E., \& Lam, S. K. (2010). The role of consensus in sales team performance. Journal of Marketing Research, 47(3), 458-469.

Akter, S., Wamba, F.S., \& Dewan, S. (2017). Why PLS-SEM is suitable for complex modelling? An empirical illustration in big data analytics quality. Production Planning \& Control, 28(11-12), 1011-1021.

Ali, F., Rasoolimanesh, S. M., Sarstedt, M., Ringle, C. M., \& Ryu, K. (2018). An assessment of the use of partial least squares structural equation modeling (PLS-SEM) in hospitality research. International Journal of Contemporary Hospitality Management, 30 (1), 514-538.

Ashley, C., \& Leonard, H. A. (2009). Betrayed by the buzz? Covert content and consumer-brand relationships. Journal of Public Policy $\mathcal{E}$ Marketing, 28(2), 212-220.

Babakus, E., Yavas, U., \&Karatepe, O. M. (2017). Work engagement and turnover intentions: Correlatesand customer orientation as a moderator. International Journal of Contemporary Hospitality Management, 29(6), 1580-1598.

Bagozzi, R. P., Verbeke, W. J., Van Den Berg, W. E., Rietdijk, W. J., Dietvorst, R. C., \& Worm, L. (2012). Genetic and neurological foundations of customer orientation: Field and experimental evidence. Journal of the Academy of Marketing Science, 40(5), 639-658.

Balaji, M. S., Roy, K. S., \& Wei, K. K. (2016). Does relationship communication matter in B2C service relationships? Journal of Services Marketing, 30(2), 186-200.

Beetles, A. C., \& Harris, L. C. (2010). The role of intimacy in service relationships: an exploration. Journal of Services Marketing, 24(5), 347-358.

Ben-Ari, A., \&Lavee, Y. (2007). Dyadic closeness in marriage: From the inside story to a conceptual model. Journal of Social and Personal Relationships, 24(5), 627-644. 
Bharadwaj, N., Nevin, J. R., \& Wallman, J. P. (2012). Explicating hearing the voice of the customer as a manifestation of customer focus and assessing its consequences. Journal of Product Innovation Management, 29(6), 1012-1030.

Bihamta, H., Jayashree, S., Rezaei, S., Okumus, F., \& Rahimi, R. (2017). Dual pillars of hotel restaurant food quality satisfaction and brand loyalty. British Food Journal, 119(12), 2597-2609.

Bolander, W., Satornino, C. B., Hughes, D. E., \& Ferris, G. R. (2015). Social networks within sales organizations: Their development and importance for salesperson performance. Journal of Marketing, 79(6), $1-16$.

Brady, M. K., \& Cronin Jr, J. J. (2001). Some new thoughts on conceptualizing perceived service quality: A hierarchical approach. Journal of Marketing, 65(3), 34-49.

Brock, K.J., \& Zhou, Y. J. (2012). Customer intimacy. Journal of Business \& Industrial Marketing, 27(5), 370-383.

Bügel, M. S., Verhoef, P. C., \& Buunk, A. P. (2011). Customer intimacy and commitment to relationships with firms in five different sectors: Preliminary evidence. Journal of Retailing and Consumer Services, 18(4), 247-258.

Carrión, G. C., Nitzl, C., \& Roldán, J. L. (2017). Mediation analyses in partial least squares structural equation modeling: Guidelines and empirical examples. In Partial least squares path modeling (pp. 173195). Springer: Cham.

Chan, S. H., \& Lay, Y. F. (2018). Examining the reliability and validity of research instruments using partial least squares structural equation modeling (PLS-SEM). Journal of Baltic Science Education, 17(2), 239-251.

Chin, W. W. (2010). How to write up and report PLS analyses. In: Esposito Vinzi, V., Chin, W.W., Henseler, J., Wang, H. (Eds.) Handbook of partial least squares (pp. 665-690). Heidelberg, Germany: Springer. 
Chin, W. W. (1998). The partial least squares approach to structural equation modeling. Modern Methods for Business Research, 295(2), 295-336.

Chou, S., \& Chen, C. W. (2018). The influences of relational benefits on repurchase intention in service contexts: the roles of gratitude, trust and commitment. Journal of Business $\mathcal{E}$ Industrial Marketing, 33(5), 680-692.

deJager, J., Cirakoglu, B., Nugter, A., \& van Os, J. (2017). Intimacy and its barriers: A qualitative exploration of intimacy and related struggles among people diagnosed with psychosis. Psychosis, 9(4), 301-309.

Deshpandé, R., Farley, J. U., \& Webster Jr, F. E. (1993). Corporate culture, customer orientation, and innovativeness in Japanese firms: a quadrad analysis. The Journal of Marketing, 57(1), 23-37.

Donavan, D. T., Brown, T. J., \&Mowen, J. C. (2004). Internal benefits of service-worker customer orientation: Job satisfaction, commitment, and organizational citizenship behaviors. The Journal of Marketing, 68(1), 128-146.

Dwyer, F. R., Schurr, P. H., \& Oh, S. (1987). Developing buyer-seller relationships. The Journal of Marketing, 51 (2), 11-27.

Fornell, C., \& Larcker, D. F. (1981). Structural equation models with unobservable variables and measurement error: Algebra and statistics. Journal of Marketing Research, (May), 382-388.

Franke, G., \& Sarstedt, M. (2019). Heuristics versus statistics in discriminant validity testing: a comparison of four procedures. Internet Research, 29(3), 430-447.

Ghazali, E. M., Mutum, D. S., \& Woon, M. Y. (2019). Multiple sequential mediation in an extended uses and gratifications model of augmented reality game Pokémon Go. Internet Research, 29 (3), 504-528.

Gottman, J. (2007), "Making relationships work." Harvard Business Review, (December), 45-50. 
Hair, J. F., Sarstedt, M., Ringle, C. M., \& Mena, J. A. (2012). An assessment of the use of partial least squares structural equation modeling in marketing research. Journal of the Academy of Marketing Science, 40(3), 414-433.

Hair Jr, J. F., Sarstedt, M., Hopkins, L., \& G. Kuppelwieser, V. (2014). Partial least squares structural equation modeling (PLS-SEM) An emerging tool in business research. European Business Review, 26(2), 106-121.

Hair Jr, J. F., Hult, G. T. M., Ringle, C., \& Sarstedt, M. (2016). A primer on partial least squares structural equation modeling (PLS-SEM) ( $2 n d$ Ed.). Thousand Oaks, USA: Sage Publications.

Hair, J. F., Hult, G. T. M., Ringle, C. M., Sarstedt, M., \& Thiele, K. O. (2017). Mirror, mirror on the wall: a comparative evaluation of compositebased structural equation modeling methods. Journal of the Academy of Marketing Science, 45(5), 616-632.

Hansen, H. (2003). Antecedents to consumers' disclosing intimacy with service employees. Journal of Services Marketing, 17(6), 573-588.

Hasan,F.E. S., Mortimer, G., Lings, I. N., \& Neale, L. (2017). Examining the antecedents and consequences of gratitude. Journal of Services Marketing, 31(1), 34-47.

Hwang, H., Takane, Y., \& Malhotra, N. (2007). Multilevel generalized structured component analysis. Behaviormetrika, 34(2), 95-109.

Hennig-Thurau, T., \&Thurau, C. (2003). Customer orientation of service employees - toward a conceptual framework of a key relationship marketing construct. Journal of Relationship Marketing, 2(1-2), 23-41.

Hennig-Thurau, T. (2004). Customer orientation of service employees: Its impact on customer satisfaction, commitment, and retention. International Journal of Service Industry Management, 15(5), 460-478.

Herrero, A., Martín, S. H., \& Collado, J. (2018). Market orientation and SNS adoption for marketing purposes in hospitality microenterprises. Journal of Hospitality and Tourism Management, 34(1), 30-40. 
Henseler, J., Ringle, C. M., \& Sarstedt, M. (2015). A new criterion for assessing discriminant validity in variance-based structural equation modeling. Journal of the Academy of Marketing Science, 43(1), 115-135.

Hsiao, C. H., Shen, G. C., \& Chao, P. J. (2015). How does brand misconduct affect the brand-customer relationship? Journal of Business Research, 68(4), 862-866.

Iacobucci, D., \& Ostrom, A. (1996). Commercial and interpersonal relationships; using the structure of interpersonal relationships to understand individual-to-individual, individual-to-firm, and firmto-firm relationships in commerce. International Journal of Research in Marketing, 13(1), 53-72.

Jeng, S. P. (2018). Enhancing the creativity of frontline employees: the effects of job complexity and customer orientation. International Journal of Logistics Management,29(1), 387-408.

Jones, T., Fox, G. L., Taylor, S. F., \& Fabrigar, L. R. (2010). Service customer commitment and response. Journal of Services Marketing, 24(1), 1628.

Kanten, P., Kanten, S., \&Baran, M. (2016). The Effect of Organizational Virtuousness on Front Line Employees' Customer Orientation: Role of Perspectionism. In 10th International Congress on Social Sciences Conference Proceedings, 2 (1), 857-874.

Kanten, P., Kanten, S., Keceli, M., \& Zaimoglu, Z. (2017). The antecedents of organizational agility: organizational structure, dynamic capabilities and customer orientation. Press Academia Procedia, 3(1), 697-706.

Kelley, S. W. (1992). Developing customer orientation among service employees. Journal of the Academy of Marketing Science, 20(1), 27-36.

Kenny, D. A., Kashy, D. A., \& Cook, W. L. (2006). The analysis of dyadic data. New York, USA: Guilford Press. 
Koo, T. K., \& Li, M. Y. (2016). A Guideline of Selecting and Reporting Intraclass Correlation Coefficients for Reliability Research. Journal of Chiropractic Medicine, 15(2), 155-163.

Lacey, R. (2007). Relationship drivers of customer commitment. Journal of Marketing Theory and Practice, 15(4), 315-333.

Laurenceau, J. P., Barrett, L. F., \& Pietromonaco, P. R. (1998). Intimacy as an interpersonal process: The importance of self-disclosure, partner disclosure, and perceived partner responsiveness in interpersonal exchanges. Journal of Personality and Social Psychology, 74(5), 1238-1251.

Leckie, C., Widing, R. E., \& Whitwell, G. J. (2017). Manifest conflict, customer orientation and performance outcomes in international buyer-seller relationships. Journal of Business $\mathcal{E}$ Industrial Marketing, 32(8), 1062-1072.

Lohmöller JB. (1989) Predictive vs. Structural Modeling: PLS vs. ML. In: Latent Variable Path Modeling with Partial Least Squares (pp.199-226). Heidelberg, Germany: Physica Press.

Lussier, B., \& Hartmann, N. N. (2017). How psychological resourcefulness increases salesperson's sales performance and the satisfaction of their customers: Exploring the mediating role of customer-oriented behaviors. Industrial Marketing Management, 62 (1), 160-170.

Nitzl, C., Roldan, J. L., \&Cepeda, G. (2016). Mediation analysis in partial least squares path modeling: Helping researchers discuss more sophisticated models. Industrial Management \& Data Systems, 116(9), 1849-1864.

Morgan, R. M., \& Hunt, S. D. (1994). The commitment-trust theory of relationship marketing. The Journal of Marketing, 58 (3), 20-38.

Pakistan Bureau of Statistics. (2015). Pakistan Statistical Book 2015. Islamabad, Pakistan: Pakistan Bureau of Statistics.

Palmatier, R. W. (2008). Relationship marketing. Cambridge, Massachusetts, USA: Marketing Science Institute. 
Palmatier, R. W., Jarvis, C. B., Bechkoff, J. R., \&Kardes, F. R. (2009). The role of customer gratitude in relationship marketing. Journal of Marketing, 73(5), 1-18.

Papaioannou, A., Kriemadis, T., Kapetaniou, P., Yfantidou, G., \& Kourtesopoulou, A. (2018). Customer Oriented Strategy and Business Performance in Tourism and Hospitality Industry. In Innovative Approaches to Tourism and Leisure (pp. 417-432). Springer, Cham.

Periatt, J. A., LeMay, S. A., \&Chakrabarty, S. (2004). The selling orientation-customer orientation (SOCO) scale: Cross-validation of the revised version. Journal of Personal Selling \& Sales Management, 24(1), 49-54.

Perlman, D., \& Fehr, B. (1986). Theories of friendship: The analysis of interpersonal attraction. In friendship and social interaction (pp. 940). Springer, New York, NY.

Podsakoff, P. M., MacKenzie, S. B., Lee, J. Y., \& Podsakoff, N. P. (2003). Common method biases in behavioral research: A critical review of the literature and recommended remedies. Journal of Applied Psychology, 88(5), 879.

Ponder, N., Holloway,B. B., \& Hansen, J. D. (2016). The mediating effects of customers' intimacy perceptions on the trust-commitment relationship. Journal of Services Marketing, 30(1), 75-87.

Richter, N. F., Cepeda-Carrión, G., Roldán, J. L., \&Ringle, C. M. (2016). European management research using partial least squares structural equation modeling (PLS-SEM). European Management Journal, 34 (6), 589-597.

Ringle, C. M., \&Sarstedt, M. (2016). Gain more insight from your PLS-SEM results: The importance-performance map analysis. Industrial Management \& Data Systems, 116(9), 1865-1886.

Ringle, Christian M., Wende, Sven, \& Becker, Jan-Michael. (2015). SmartPLS 3. Bönningstedt: SmartPLS. Retrieved from http://www.smartpls.com. 
Ro, H., \& Chen, P. J. (2011). Empowerment in hospitality organizations: Customer orientation and organizational support. International Journal of Hospitality Management, 30(2), 422-428.

Rokach, A., \& Philibert-Lignières, G. (2015). Intimacy, loneliness \& infidelity. The Open Psychology Journal, 8(1), 72-77.

Rungtusanatham, M., Miller, J. W., \& Boyer, K. K. (2014). Theorizing, testing, and concluding for mediation in SCM research: Tutorial and procedural recommendations. Journal of Operations Management, 32(3), 99-113.

Rusbult, C. E. (1980). Commitment and satisfaction in romantic associations: A test of the investment model. Journal of Experimental Social Psychology, 16(2), 172-186.

Saxe, R., \&Weitz, B. A. (1982). The SOCO scale: A measure of the customer orientation of salespeople. Journal of Marketing Research, 19 (3), 343351.

Schaefer, M. T., \& Olson, D. H. (1981). Assessing intimacy: The PAIR inventory. Journal of Marital and Family Therapy, 7(1), 47-60.

Sousa, C. M., \& Coelho, F. (2011). From personal values to creativity: evidence from frontline service employees. European Journal of Marketing, 45(7/8), 1029-1050.

Stern, B. B. (1997). Advertising intimacy: Relationship marketing and the services consumer. Journal of Advertising, 26(4), 7-19.

Sternberg, R. J. (1986). A triangular theory of love. Psychological Review, 93(2), 119-135.

Srivastava, P., \& Owens, D. L. (2010). Personality traits and their effect on brand commitment: an empirical investigation. Marketing Management Journal, 20(2), 15-27.

Tardivo, G., Thrassou, A., Viassone, M., \& Serravalle, F. (2017). Value cocreation in the beverage and food industry. British Food Journal, 119(11), 2359-2372. 
Varghese, J., Edward, M., \& George, B. P. (2017). Centralization of authority, market orientation, and customer relationship management in the banking sector: a study in India. Management and Economics Review, 2(1), 90-100.

Yim, C. K., Tse, D. K., \& Chan, K. W. (2008). Strengthening customer loyalty through intimacy and passion: Roles of customer-firm affection and customer-staff relationships in services. Journal of Marketing Research, 45(6), 741-756.

Zablah, A. R., Franke, G. R., Brown, T. J., \& Bartholomew, D. E. (2012). How and when does customer orientation influence frontline employee job outcomes? A meta-analytic evaluation. Journal of Marketing, 76(3), 21-40.

Zhang, H., \& Yang, F. (2018). The impact of customer orientation on new product development performance: the role of top management support. International Journal of Productivity and Performance Management, 67(3), 590-607.

Zhao, X., Lynch Jr, J. G., \& Chen, Q. (2010). Reconsidering Baron and Kenny: Myths and truths about mediation analysis. Journal of Consumer Research, 37(2), 197-206. 
Annexure-1

\section{Items of Constructs}

\begin{tabular}{|c|c|c|c|}
\hline Number & Construct & Items & Reference \\
\hline 1 & $\begin{array}{l}\text { Customer } \\
\text { Orientation }\end{array}$ & $\begin{array}{l}\text { 1. We have routine and regular measures of customer } \\
\text { service. } \\
\text { 2. Our product and service development is based on } \\
\text { good market and customer information. } \\
\text { 3. We know our competitors well. } \\
\text { 4. We have a good sense of how our customers value } \\
\text { our products and services. } \\
\text { 5. We are more customer focused than our } \\
\text { competitors. } \\
\text { 6. We compete primarily based on product and } \\
\text { service differentiation. } \\
\text { 7. The customer's interest should always come first, } \\
\text { ahead of the owners. } \\
\text { 8. Our products and services are the best in the } \\
\text { business. } \\
\text { 9. We believe our business exists primarily to serve } \\
\text { customers. }\end{array}$ & $\begin{array}{l}\text { Deshpande, } \\
\text { Farley, and } \\
\text { Webster } \\
\text { (1993) }\end{array}$ \\
\hline 2 & $\begin{array}{l}\text { Salesperson } \\
\text { Customer- } \\
\text { oriented } \\
\text { Behavior }\end{array}$ & $\begin{array}{l}\text { 1. The sales representative tries to satisfy me instead } \\
\text { of selling the product or service. } \\
\text { 2. The sales representative necessarily tries totell } \\
\text { truth in describing a product or service to me. } \\
\text { 3. The sales representative only convincesme to buy; } \\
\text { when he/she think it is wise for meto buy. } \\
\text { 4. The sales representative paint true picture of } \\
\text { product or service to sound as good as possible. } \\
\text { 5. The sales representative offer on the basis of what } \\
\text { will satisfy me in the long run. }\end{array}$ & $\begin{array}{l}\text { Periatt, } \\
\text { LeMay, and } \\
\text { Chakrabarty } \\
\text { (2004) }\end{array}$ \\
\hline 3 & Intimacy & $\begin{array}{l}\text { 1. You always enjoy your experience with your brand } \\
\text { 2. You always have a warm and comfortable feeling } \\
\text { when visiting to your brandYou experience great } \\
\text { happiness with visiting to your brand }\end{array}$ & $\begin{array}{l}\text { Balaji, Roy, } \\
\text { and Wei } \\
\text { (2016) }\end{array}$ \\
\hline 4 & Commitment & $\begin{array}{l}\text { 1. I am willing "to go the extra mile" to remain a } \\
\text { customer of my brand } \\
\text { 2. I feel loyal towards my brand } \\
\text { 3. Even if my brand would be more difficult to reach, } \\
\text { I would still keep buying from my brand }\end{array}$ & $\begin{array}{l}\text { Balaji, Roy, } \\
\text { and Wei } \\
(2016)\end{array}$ \\
\hline
\end{tabular}

